\title{
The Assessment of short-term effect of L-Citrulline on endothelial function via FMD to NMD ratio in known CAD patients: A randomized, cross-over clinical trial (Clinical trial number: NCT02638727)
}

\author{
MORTEZA SAFI ${ }^{1}$, MOHAMMAD PARSA MAHJOOB ${ }^{1}$, SAEED NATEGHI ${ }^{1}$, ISA KHAHESHI ${ }^{1}$, MOHAMMAD ALI \\ AKBARZADEH $^{1}$, MOHAMMADREZA NADERIAN $^{2}$ \\ ${ }^{1}$ Cardiovascular Research Center, Shahid Beheshti University of Medical Sciences, Tehran, Iran \\ ${ }^{2}$ Non-Communicable Diseases Research Center, Endocrinology and Metabolism Population Sciences Institute, Tehran University of \\ Medical Sciences, Tehran, Iran. Students' Scientific Research Center (SSRC), Tehran University of Medical Sciences, Tehran, Iran
}

\begin{abstract}
Background. Recent studies have confirmed the essential and paramount role of the L-Citrulline on the nitric oxide regulation and the endothelial function improvement.

Materials and Methods. In this cross-over clinical trial, thirty patients, diagnosed with coronary artery disease $(\mathrm{CAD})$ and flow mediated dilation to nitroglycerin dependent vasodilation (FMD/NMD) ratio less than 1, were included. The patients were randomly divided into two groups of 15 patients and underwent treatment by L-Citrulline or placebo for 15 days, in 2 step protocol. The indicators of assessment in the current study were the ratio of the FMD/NMD and FMD value.

Results. In the current cross-over clinical trial, the mean of FMD to NMD ratio and mean FMD value of all patients before starting the protocol were $0.91 \pm 0.08$ and $4.04 \pm 0.51 \mathrm{~mm}$, respectively. The final results of study showed that following L-Citrulline administration, mean FMD to NMD ratio and mean FMD value were enhanced to: $1.03 \pm 0.09$ and $4.96 \pm 0.72 \mathrm{~mm}$, respectively, which were statistically significant $(\mathrm{P}<0.001$ and $\mathrm{P}<0.001$, respectively). However, following placebo administration, mean FMD to NMD ratio and mean FMD value were receded to: $0.92 \pm 0.09$ and $4.06 \pm$ $0.22 \mathrm{~mm}$, respectively, which were not statistically significant $(\mathrm{P}=0.75$ and $\mathrm{P}=0.89$, respectively). Moreover, the improvement of mean FMD to NMD ratio $(0.12 \pm 0.02)$ and mean FMD value $(0.92 \pm$ $0.16 \mathrm{~mm}$ ), following L-Citrulline administration, were statistically significant in comparison with the change of mean FMD to NMD ratio $(0.01 \pm 0.002)$ and mean FMD value $(0.02 \pm 0.003)$, following placebo administration $(\mathrm{P}<0.001$ and $\mathrm{P}<0.001$, respectively).

Conclusion. L-Citrulline treatment can lead to improvement of the endothelial function in patients diagnosed with CAD which are assessed via FMD to NMD ratio FMD value enhancements.
\end{abstract}

Keywords: L-Citrulline, Nitric Oxide, Endothelium, Coronary Artery Disease.

\section{INTRODUCTION}

L-Citrulline functions as a metabolic mediator in the urea cycle [1-3]. Recent studies have indicated its effective role in the nitric oxide regulation [4]. Production of nitric oxide by endothelial cells is essential for the normal function of endothelium and depends on the L-Arginine substrate. Endothelial dysfunction is considered as the key factor in the disability and mortality caused by cardiovascular diseases. Endothelial dysfunction, as a disorder of endothelial relaxation, interferes with the nitric oxide accessibility and activity $[5,6]$.

L-Citrulline functions as an imperative factor in the nitric oxide production through transformation into the L-Arginine. Unlike the L-Arginine, L-Citrulline bypasses liver metabolism and is not considered as a substrate for Arginase [7, 8]. L-Citrulline administration has a stimulating role in the L-Arginine production. Various studies indicate that L-Citrulline proper function can be more effective than the prescription of the L-Arginine itself. L-Citrulline, as compared with L-Arginine in equal doses, is able to provide more L-Arginine plasma level. This difference is a result of lack of L-Citrulline absorption in the liver and intestinal organs. Several studies have indicated that oral consumption of L-Citrulline could increase the expression of nitric oxide synthetase (NOS) enzyme that has a significant role in nitric oxide production [9-12].

In this crossover clinical study, the efficacy of L-Citrulline oral consumption on endothelial function and vasodilation was assessed.

\section{MATERIALS AND METHODS}

This randomized clinical study was conducted on 70 patients with known CAD that was defined 
as significant stenosis $(>50 \%)$ in at least one of major epicardial arteries. A written informed consent was taken from all participants and the institutional review board approved the trial (Clinical trial number: NCT02638727).

The patient's condition was evaluated by an experienced radiologist via the ultrasound machine equipped with the vascular software according to the guidelines for the assessment of the FMD. The patients rested for 10 minutes in a calm room that had an appropriate temperature $\left(22-25^{\circ} \mathrm{C}\right)$. They avoid the exercise, consumption of fatty foods, tobacco, coffee, vitamin $\mathrm{C}$ and sympathetic stimulant drugs for 8-12 hours before the ultrasonography. After resting for 10 minutes, the brachial artery diameter in the antecubital area was measured by the ultrasound and was recorded. Then blood pressure cuff was attached on the arm and dilated $50 \mathrm{mmHg}$ above the systolic pressure and, remained at the same level for 5 minutes to induce ischemia at distal of the upper extremity until the occurrence of compensatory vasodilation. After 5 minutes the cuff was deflated, and one minute after deflation of the cuff for the second time, the brachial artery diameter (as an estimation of FMD) was measured and recorded. Then the patient rested for 10 minutes and then 2 puffs of nitroglycerin spray were introduced sublingually; 4 minutes later, the brachial artery diameter was measured (as an estimation of NMD). Finally, the FMD to NMD ratio was calculated; Patients who had FMD to NMD ratio less than 1 were included in the study. 40 patients were excluded because their FMD to NMD ratio was 1 or more. Then the remained 30 patients were divided into two equal groups by simple randomization with computergenerated random allocation sequence. One group was treated with L-Citrulline for 15 days and the other group with placebo with the same duration; at the end of this period, the patients underwent the ultrasonography again and the above assessments were done and compared with the data obtained before starting the therapeutic period. Then the patients in both groups were kept from receiving L-Citrulline or placebo for 15 days [13]; After 15 days, the crossover was performed as the last step of clinical study; The patients who had been treated with L-Citrulline in the first stage were given placebo for 15 days, and the patients who had received placebo, received L-Citrulline for 15 days. At the end of 15 days the evaluation was performed again through ultrasonography and with a similar method as in the previous step (Figure 1).

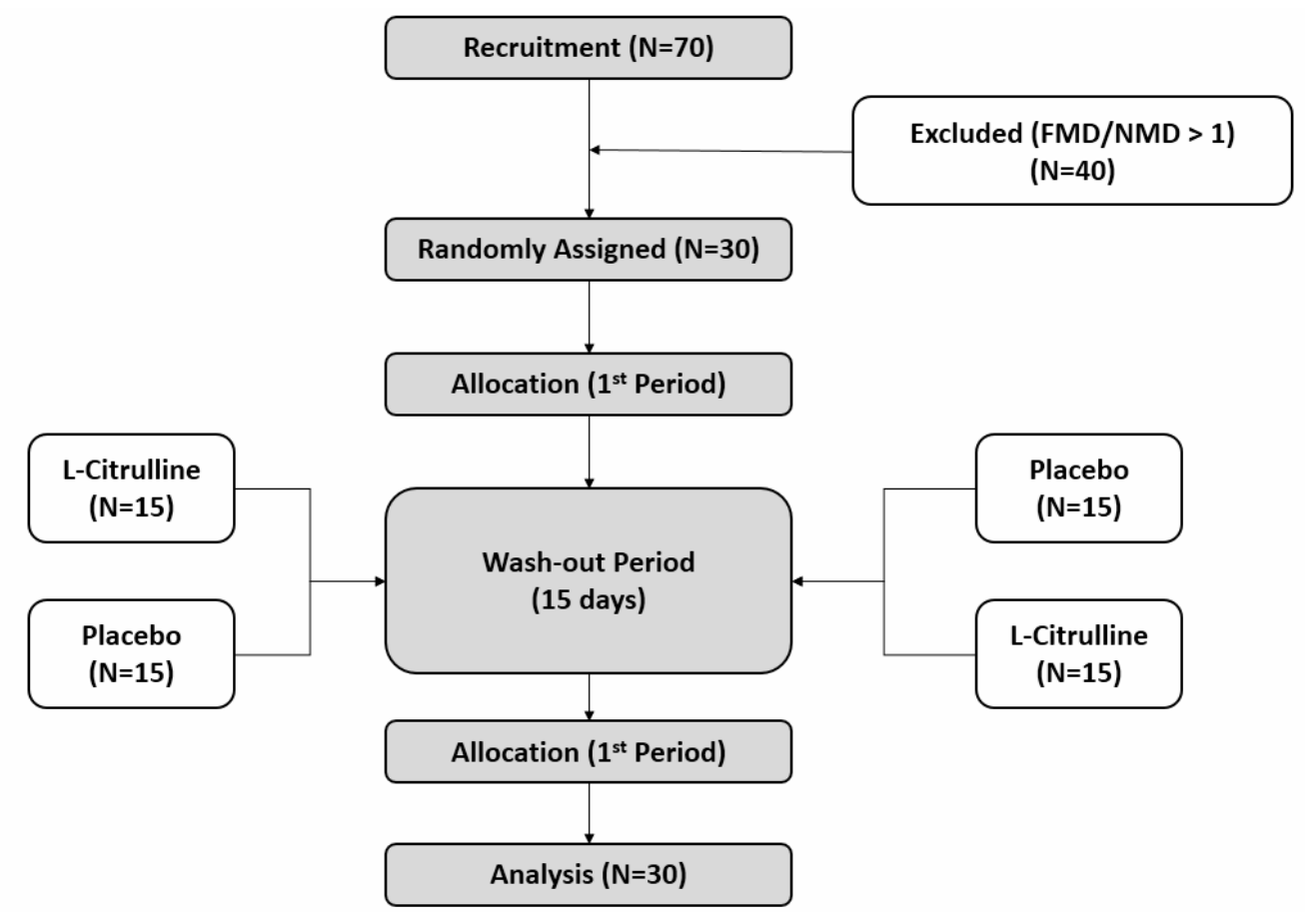

Figure 1. Patient allocation.

Quantitative variables were shown as mean \pm $\mathrm{SD}$ and for the qualitative variables as percentage. The Chi-Square test was used for the qualitative variables and paired T-Test was used for the analysis of the dependent quantitative variables. For independent quantitative variables, we used 
independent sample T-Test. For statistical analysis of the data, the SPSS software (version 19) was used. A P-value less than 0.05 was considered statistically significant.

\section{RESULTS}

The demographic characteristics and prevalence of the cardiovascular risk factors of all 30 included patients are provided in Table 1 . The patients were categorized in 2 groups (each group contained 15 cases), via computer randomization. The mean of FMD to NMD ratio and mean FMD value of all patients before starting the protocol were $0.91 \pm$ 0.08 and $4.04 \pm 0.51 \mathrm{~mm}$, respectively. The final results of study showed that, following L-Citrulline administration, mean FMD to NMD ratio and mean FMD value were enhanced to: $1.03 \pm 0.09$ and $4.96 \pm$ $0.72 \mathrm{~mm}$, respectively, which were statistically significant $(\mathrm{P}<0.001$ and $\mathrm{P}<0.001$, respectively). However, following placebo administration, mean FMD to NMD ratio and mean FMD value were receded to: $0.92 \pm 0.09$ and $4.06 \pm 0.22 \mathrm{~mm}$, respectively, which were not statistically significant $(\mathrm{P}=0.75$ and $\mathrm{P}=0.89$, respectively). Moreover, the improvement of mean FMD to NMD ratio $(0.12 \pm$ $0.02)$ and mean FMD value $(0.92 \pm 0.16 \mathrm{~mm})$, following L-Citrulline administration, were statistically significant in comparison with the change of mean FMD to NMD ratio $(0.01 \pm 0.002)$ and mean FMD value $(0.02 \pm 0.003)$, following placebo administration on $(\mathrm{P}<0.001$ and $\mathrm{P}<0.001$, respectively).

Table 1

Demographic characteristics and prevalence of the cardiovascular risk factors of all randomized patients

\begin{tabular}{|l|c|}
\hline \multicolumn{1}{|c|}{ Characteristics } & N (\%), Mean (SD) \\
\hline Gender (Male) & $18(60.0)$ \\
\hline Age & $56.52 \pm 8.44$ \\
\hline Hypertension & $17(56.67)$ \\
\hline Hyperlipidemia & $15(50.0)$ \\
\hline Smoking & $16(53.3)$ \\
\hline Family history of CAD & $12(40.0)$ \\
\hline Diabetes & $14(46.67)$ \\
\hline Obesity & $5(16.67)$ \\
\hline
\end{tabular}

Abbreviation: CAD: Coronary artery disease.

Table 2

Mean FMD value and FMD/NMD ratio at baseline, after L-Citrulline and placebo administration

\begin{tabular}{|c|c|c|c|c|c|c|c|c|}
\hline & Baseline & $\begin{array}{c}\text { After } \\
\text { L-Citrulline } \\
\text { administration }\end{array}$ & $\begin{array}{l}\text { Change from } \\
\text { baseline with L- } \\
\text { Citrulline }\end{array}$ & Pvalue & $\begin{array}{c}\text { After Placebo } \\
\text { administration }\end{array}$ & $\begin{array}{c}\text { Change from } \\
\text { baseline with } \\
\text { Placebo } \\
\end{array}$ & Pvalue $^{\$}$ & Pvalue $^{\&}$ \\
\hline Mean FMD value(mm) & $4.04 \pm 0.51$ & $4.96 \pm 0.72$ & $0.92 \pm 0.16$ & $\mathrm{P}<0.001$ & $4.06 \pm 0.22$ & $0.02 \pm 0.003$ & 0.89 & $<0.001$ \\
\hline Mean FMD/NMD ratio & $0.91 \pm 0.08$ & $1.03 \pm 0.09$ & $0.12 \pm 0.02$ & $\mathrm{P}<0.001$ & $0.92 \pm 0.09$ & $0.01 \pm 0.002$ & 0.75 & $<0.001$ \\
\hline
\end{tabular}

"P value for "Baseline" vs "L-Citrulline"

${ }^{\$} \mathrm{P}$ value for "Baseline" vs "placebo"

\&P value for "L-Citrulline" vs "Placebo"

\section{DISCUSSION}

The present study aimed to assess the role of the L-Citrulline treatment on vascular endothelial function, based on FMD to NMD ratio. Few studies have addressed the issue of the effect of this medication on the vascular endothelial function and almost all of these studies emphasize on the high efficacy of this medication on the vascular endothelial function. This study, however, uses a crossover clinical study in order to compare medication efficacy with the placebo; therefore, the effect of confounding factors was eliminated. Two groups including fifteen patients were assessed and the medication effect on the FMD to the NMD ratio was evaluated. As the final point, the results indicated that the L-Citrulline prescription significantly improved vascular endothelial function as well as the FMD to NMD ratio. Whereas the two groups of the study equalized with each other, this pharma- ceutical effect could not be influenced by background factors including the demographic and coronary risk factors.

A review of the previous studies indicates on the helpful effect of L-Citrulline on the endothelial function. In one study in 2010 in Mexico, the L-Arginine and the L-Citrulline effect on the vascular endothelial function was assessed in patients with diastolic heart failure. 30 patients underwent photoplethysmography via hyperemic techniques. The finger flow indicators at the basic time and also after ischemia for 30 seconds were measured by the MAT, total time of the TT curve and the MAT to TT ratio before and after prescription of 8 grams of L-Arginine per day, or 3 grams of L-Citrulline per day for 60 days.

The two groups were identical in terms of the basic characteristics. After performing of the intervention, the MAT to TT indicator was considerably decreased in comparison with the basic 
time; in manner that in L-Arginine group reduced from 38.75 to 23.32 and in the group under treatment of L-Citrulline reduced from 41.40 to 23.65 .

Therefore, both of these two medications accompanied with improvement of the endothelial function via making balance in in the MAT to TT ratio [14]. In our study L-Citrulline prescription significantly improved vascular endothelial function as well as the FMD to NMD ratio.

In another investigation, conducted in 2012 in Mexico, the effects of the L-Citrulline on the functional class, the left ventricle ejection fraction (LVEF) and peripheral vascular flow in patients suffering from the systolic heart failure, were assessed. 37 patients underwent clinical assessment including the radioisotope, ventriculography and photo-plethysmography before and 4 months after the treatment. The patients were divided into two groups including: one group under treatment with L-Citrulline (3 grams per day) and the other the control group was treated with placebo. In the L-Citrulline, LVEF accompanied with 20.3\% increase at the rest time and $12.7 \%$ increase at the stress time. In addition, right ventricle ejection fraction (RVEF) revealed $15.1 \%$ increase at the rest time and $14.8 \%$ increase at the stress time. The functional class was improved at a rate of $35 \%$ and the MAT to TT ratio also decreased at a rate of $23 / 1 \%$. These changes were not observed in the control group [15].
Another investigation, in animal model, evaluated L-Citrulline and D-Citrulline effect on the cardiac function. In this study, the selected animal underwent 20 minutes of ischemia and 40 minutes of reperfusion. The reperfused hearts with L-Citrulline or the D-Citrulline showed improvement in left ventricular pressure and volume [16].

In another study in 2010, treatment with L-Arginine and L-Citrulline revealed significant improvement in right ventricular ejection fraction and considerable decrease in pulmonary arterial pressure in comparison to the control group [17].

It is inevitable that the number of the patients that enrolled in our study was relatively small. Our study is a pilot study that showed remarkable improvement in endothelial function that was assessed by FMD/NMD ratio and FMD value in patients with known CAD. Future studies with large sample size are recommended to uncover detailed benefits of L-Citrulline on endothelial function. As another limitation, we had limited financial resources for developing our study to a large population.

\section{CONCLUSION}

L-Citrulline treatment can lead to significant improvement of the endothelial function in patients diagnosed with CAD which are assessed via FMD to NMD ratio and FMD value enhancements.

Conflict of interest. The authors declare no conflict of interest.

Introducere. Studii recente au confirmat rolul esențial al L-citrulinei pin reglarea nivelurilor oxidului nitric şi a îmbunătățirii funcției endoteliale.

Materiale şi Metode. A fost realizat un studiu clinic randomizat cross-over în care au fost incluşi 30 de pacienți diagnosticați cu boală coronariană ischemică (BCI) şi raport FND/NMD mai mic de 1. Pacienții au fost randomizați în 2 grupuri de 15 pacienți şi au primit tratament cu L-citrulină sau placebo într-un protocol ce a avut 2 paşi. Valorile analizate au fost valoarea FMD şi a raportului FMD/NMD.

Rezultate. In acest studiu cross-over, media FMD/NMD şi a FMD a fost de $0.91 \pm 0.08$ şi respectiv $4.04 \pm 0.51 \mathrm{~mm}$ la pacienții înrolați înainte de a fi inițiat protocolul. Rezultatele finale arată că după administrarea L-citrulinei media raportului FMD/NMD precum şi media FMD au fost îmbunătățite la $1.03 \pm 0.09$ şi respectiv $4.96 \pm 0.72 \mathrm{~mm}(p<0.001)$. După administrarea placebo valorile acestea au scăzut din nou la valorile similare înaintea inițierii studiului $0.92 \pm 0.09$ şi respectiv $4.06 \pm 0.22 \mathrm{~mm}$, $(p=0.75$ şi $p=0.89)$. Mai mult, imbunătățirea după administrarea L-citrulinei a FMD/NMD $(0.12 \pm 0.02)$ şi valoarea medie a FMD $(0.92 \pm 0.16 \mathrm{~mm})$ au fost semnificative comparativ cu modificările acestor parametri după administrarea placebo (FMD/NMD $0.01 \pm 0.002$, respectiv $0.02 \pm$ 0.003 pentru FMD, $p<0.001$ ). 
Concluzii. Tratamentul cu L-citrulină poate duce la îmbunătățirea funcției endoteliale la pacienții diagnosticați cu BCI şi care sunt evaluați folosind parametrii FMD şi raportul FMD/NMD.

Correspondence to: Mohammad Parsa Mahjoob, MD

Cardiovascular Research Center, Shahid Beheshti University of Medical Sciences, Tehran, Iran

E-mail: heartcenter87@yahoo.com

\section{REFERENCES}

1. ABOU-MOHAMED G., JOHNSON JA., JIN L., EL-REMESSY AB., DO K., KAESEMEYER WH., et al. Roles of superoxide, peroxynitrite, and protein kinase $C$ in the development of tolerance to nitroglycerin. J Pharmacol Exp Ther. 2004; 308 (1):289-99.

2. ASAGA H., ISHIGAMI A. Protein deimination in the rat brain after kainate administration: citrulline-containing proteins as a novel marker of neurodegeneration. Neurosci Lett. 2001; 299 (1-2):5-8.

3. BAYDOUN AR., BOGLE RG., PEARSON JD., MANN GE. Discrimination between citrulline and arginine transport in activated murine macrophages: inefficient synthesis of NO from recycling of citrulline to arginine. Br J Pharmacol. $1994 ; 112$ (2):487-92.

4. BERKOWITZ DE., WHITE R., LI D., MINHAS KM., CERNETICH A., KIM S., et al. Arginase reciprocally regulates nitric oxide synthase activity and contributes to endothelial dysfunction in aging blood vessels. Circulation. 2003; 108 (16):2000-6.

5. DILLON EL., KNABE DA., WU G. Lactate inhibits citrulline and arginine synthesis from proline in pig enterocytes. Am J Physiol. 1999; 276 (5 Pt 1):G1079-86.

6. DONG S., KOJIMA T., SHIRAIWA M., MECHIN MC., CHAVANAS S., SERRE G., et al. Regulation of the expression of peptidylarginine deiminase type II gene (PADI2) in human keratinocytes involves Sp1 and Sp3 transcription factors. J Invest Dermatol. 2005; 124 (5):1026-33.

7. INOUE Y., COPELAND EM., SOUBA WW. Growth hormone enhances amino acid uptake by the human small intestine. Ann Surg. 1994; 219 (6):715-22; discussion 22-4.

8. ISHIGAMI A., OHSAWA T., ASAGA H., AKIYAMA K., KURAMOTO M., MARUYAMA N. Human peptidylarginine deiminase type II: molecular cloning, gene organization, and expression in human skin. Arch Biochem Biophys. 2002; 407 (1):25-31.

9. CREAGER MA., COOKE JP., MENDELSOHN ME., GALLAGHER SJ., COLEMAN SM., LOSCALZO J., et al. Impaired vasodilation of forearm resistance vessels in hypercholesterolemic humans. J Clin Invest. 1990; 86 (1):228-34.

10. CURIS E., NICOLIS I., MOINARD C., OSOWSKA S., ZERROUK N., BENAZETH S., et al. Almost all about citrulline in mammals. Amino Acids. 2005; 29 (3):177-205.

11. JEAN C., ROME S., MATHE V., HUNEAU JF., AATTOURI N., FROMENTIN G., et al. Metabolic evidence for adaptation to a high protein diet in rats. J Nutr. 2001; 131 (1):91-8.

12. JEREMY RW., MCCARRON H., SULLIVAN D. Effects of dietary L-arginine on atherosclerosis and endothelium-dependent vasodilatation in the hypercholesterolemic rabbit. Response according to treatment duration, anatomic site, and sex. Circulation. 1996; 94 (3):498-506.

13. SANCHEZ-GONZALEZ MA., KOUTNIK AP., RAMIREZ K., WONG A., FIGUEROA A. The effects of short term L-citrulline supplementation on wave reflection responses to cold exposure with concurrent isometric exercise. Am J Hypertens. $2013 ; 26$ (4):518-26.

14. OREA-TEJEDA A., OROZCO-GUTIERREZ JJ., CASTILLO-MARTINEZ L., KEIRNS-DAVIES C., MONTANOHERNANDEZ P., VAZQUEZ-DIAZ O., et al. The effect of L-arginine and citrulline on endothelial function in patients in heart failure with preserved ejection fraction. Cardiol J. 2010; 17 (5):464-70.

15. BALDERAS-MUNOZ K., CASTILLO-MARTINEZ L., OREA-TEJEDA A., INFANTE-VAZQUEZ O., UTRERA-LAGUNAS M., MARTINEZ-MEMIJE R., et al. Improvement of ventricular function in systolic heart failure patients with oral L-citrulline supplementation. Cardiol J. 2012; 19 (6):612-7.

16. IKEDA Y., YOUNG LH., SCALIA R., LEFER AM. Cardioprotective effects of citrulline in ischemia/reperfusion injury via a non-nitric oxide-mediated mechanism. Methods Find Exp Clin Pharmacol. 2000; 22 (7):563-71.

17. OROZCO-GUTIERREZ JJ., CASTILLO-MARTINEZ L., OREA-TEJEDA A., VAZQUEZ-DIAZ O., VALDESPINO-TREJO A., NARVAEZ-DAVID R., et al. Effect of L-arginine or L-citrulline oral supplementation on blood pressure and right ventricular function in heart failure patients with preserved ejection fraction. Cardiol J. 2010; 17 (6):612-8.

Received July 4, 2016 